\title{
Editorial
}

\section{Mitreden erwünscht}

_ „Ihr dürft alles behaupten, solange ihr überzeugend argumentieren könnt.“ Dieser überspitzte Freifahrschein meiner Dozenten im Ergotherapiestudium hat seine Wirkung gezeigt: Wir Studenten haben Thesen aufgestellt, diskutiert, Fragen gestellt, kritisiert, Themen von verschiedenen Seiten beleuchtet und letztendlich alle davon profitiert, weil wir über den Austausch gelernt haben.

_ Natürlich gab es auch immer Kandidaten, die zu allem und jedem etwas zu sagen hatten. Die es verstanden, Dinge totzudiskutieren, oder die sich niemals auf der Sach-, sondern prinzipiell auf der Beziehungsebene bewegten. Auf konstruktive Beiträge wartete man bei ihnen vergeblich.

_ Ein fachlicher Austausch jedoch, der unterschiedliche Sichtweisen zulässt, konstruktiv und zugleich lehrreich ist, entspricht genau unseren Vorstellungen bei ergopraxis. Ihre Leserbriefe bestärken uns darin und beflügeln uns für unsere Arbeit. Ein Ergebnis davon ist unsere Rechtsrubrik - dieses Mal auf Seite 38. Ihre Anregungen ermöglichen hier ab sofort einen Dialog, indem unser Experte rechtliche Fragen aus Ihrem Berufsalltag beantwortet.

_ Reden Sie also mit und trauen Sie sich, Ihre Meinung zu sagen - auch wenn Sie damit gelegentlich anecken. Mit überzeugenden Argumenten geben Sie Ihren Kollegen die Chance, davon zu profitieren.

Herzlichst Ihre

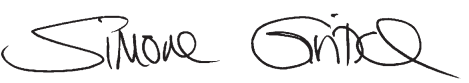

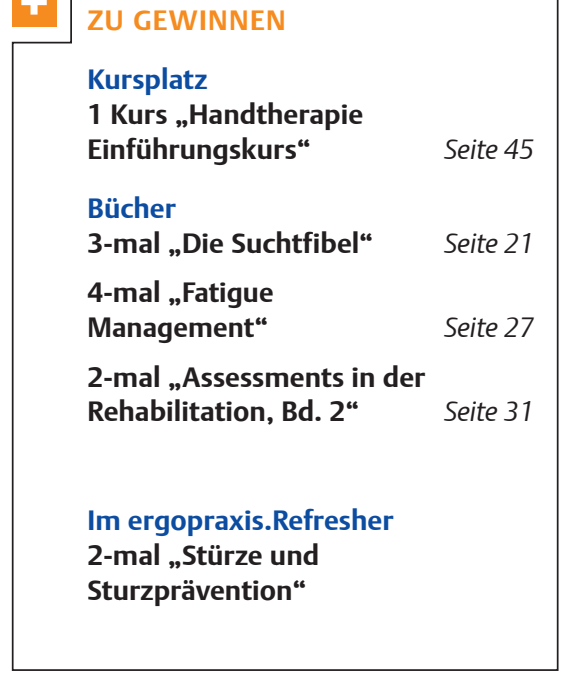

